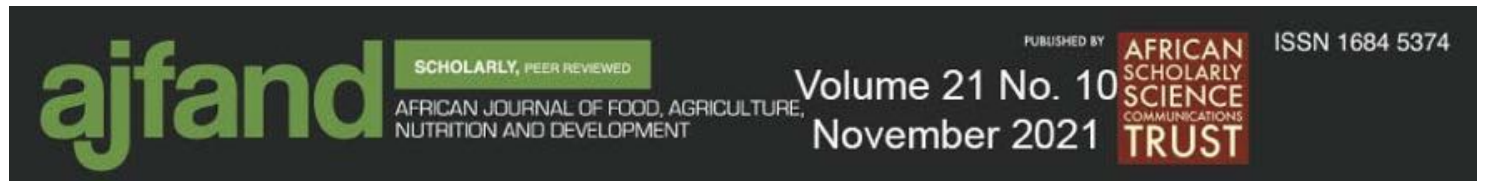

Afr. J. Food Agric. Nutr. Dev. 2021; 21(10): 18965-18979 https://doi.org/10.18697/ajfand.105.21395

\title{
PROXIMATE COMPOSITION AND SENSORY CHARACTERISTICS OF REFRACTANCE WINDOW DRIED COWPEA COMPOSITE PORRIDGES
}

Wasswa MS ${ }^{1}$, Fungo $\mathrm{R}^{2 *}$, Kaaya $\mathrm{A}^{1}$ and $\mathrm{JH}_{\text {Muyonga }}{ }^{1}$

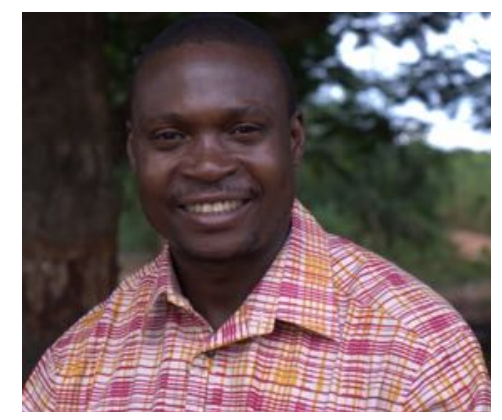

Robert Fungo

*Corresponding author email: rfungom@yahoo.com

${ }^{1}$ School of Food Technology, Nutrition \& Bioengineering, Makerere University, P.O. Box 7062, Kampala Uganda

${ }^{2}$ The Alliance of Bioversity International and The International Center for Tropical Agriculture (CIAT) Kawanda, Uganda 


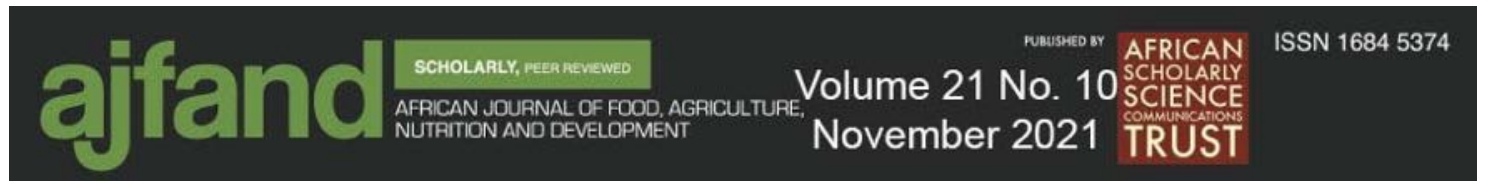

\begin{abstract}
Undernutrition is a major public health concern in Uganda. Locally available nutrient dense diets can help reduce the problem of undernutrition. Utilisation of cowpea leaf powder in preparing composite porridge blends depends on sensory acceptance of the consumers. A Nutrisurvey software was used to formulate two composite flour blends, namely maize and millet in a ratio $2: 8$ and cowpea-maize in a ratio of 1:9 to achieve the daily requirement of protein for children. The study developed a process for the production of composite cowpea flour from finger millet flour and maize flour and followed a one factor design in which maize flour (MF) and millet flour (MMF) was substituted with cowpea leaves flour (CPL). The composites were dried using refractance window drying technology. The proximate composition of the composite flours were determined using standard methods while sensory acceptability of porridges was rated on a five-point Likert scale using an untrained panel. Results indicated a significant $(\mathrm{p}<0.05)$ increase in protein $(10.9$ to $13.4 \%)$, dietary fibre (11.01 to $13.0 \%$ ) and lipids (4.71 to 5.3\%) contents for cowpea-millet composite porridge. For cowpea-maize composite flour, a significant $(\mathrm{p}<0.05)$ increase in protein (5.9 to $7.6 \%$ ), dietary fibre (1.47 to $3.3 \%$ ) and lipids (2.84 to $3.3 \%$ ) was also observed. Sensory evaluation indicated that between the two composite porridges, the cowpeamillet porridge blend was significantly $(\mathrm{P} \leq 0.05)$ more appealing in terms of colour (3.61 \pm 0.8$)$, aroma $(2.96 \pm 0.2)$, taste $(3.24 \pm 0.6)$, texture $(3.62 \pm 0.6)$ and general acceptability $(3.61 \pm 0.8)$ to the panellists than the cowpea-maize porridge blend. The cowpea-millet and cowpea-maize composite flours can contribute more than $100 \%$ of the recommended dietary allowance of protein and carbohydrate requirements for children aged 0-8 years. The study findings indicate that the cowpea-based composite flours have the potential to make a significant contribution to the improvement in the nutritional status of infants and children in developing countries.
\end{abstract}

Key words: Composite flours, Recommended Dietary Allowance (RDA), sensory attributes, refractance window drying (RWD) 


\section{INTRODUCTION}

In Uganda, cowpea (Vigna unguiculata (L). Walp) is the fourth most consumed legume, after beans, groundnuts and soybeans [1], a crop with potential to create employment especially among women and the youth [2]. It is recommended to use locally available crops such as cowpeas, to sustainably address the high food and nutrition insecurity challenges in Uganda [3]. This would complement existing strategies such as fortification and supplementation by offering a sustainable and low cost way to reach people with poor access to health care and food systems [4]. Cowpea is a rich source of essential nutrients; vitamin C (70-203g/100g), carotenoids (32.74$36.55 \mathrm{mg} / 100 \mathrm{~g})$, iron $(66-75 \mathrm{mg} / 100 \mathrm{~g})$, calcium $(17.1-39.87 \mathrm{mg} / 100 \mathrm{~g})$, zinc $(5.22-12.91$ $\mathrm{mg} / 100 \mathrm{~g})$, proteins $(28-42 \mathrm{~g} / 100 \mathrm{~g})$, total essential amino acids $(0.027-0.031 \mathrm{mg} / 100 \mathrm{~g})$ and crude fibre $(10.09-25.51 \mathrm{~g} / 100 \mathrm{~g})[4,6,7]$. As a result of possessing considerably high nutrient content, cowpeas leafy vegetables have the potential to boost the nutrient content of less nutritious foods [8]. Within rural African settings, a number of dishes are served with cowpea leaves as an accompaniment to or as a side dish in order to have a balanced diet [9].

There is a growing trend in Uganda and the rest of Africa, to promote the use of composite flours developed using locally grown legumes and other cereals that are nutrient rich [10]. The quality of the products that are made from combinations of cereals and legumes, depend on the individual proportions of the composite constituents. Furthermore, the refractance window drying (RWD) technology has been documented by Nindo et al. [11] as a feasible drying technology for production of highquality products. The RWD dryers are a superior alternative to conventional commercial dryers especially among small-scale processors in Africa. RWD dryers are mechanically simpler to operate, compared to commercial dryers and better in retaining nutrients due its faster drying of foods. The retained nutrients can go a long way in addressing the unacceptably high nutrition disorders in rural settings of Africa. It involves a thin film drying system having high heat and mass transfer rates that speed up the rate of drying at a comparatively lower temperature [11,12]. Additionally, RWD is a more reliable, efficient and cheaper drying method with better retention of the product's natural colour and aroma compared to conventional drying methods such as sun drying [12]. For the aforementioned reasons, cowpea leaves in Uganda would best be dried using the RWD technology. Previous work on composite cowpea leaves flours has been documented on nutritional and functional properties of composite cowpea flours and its blends with sorghum [13], African yam bean [14], peanut [15], bambara groundnuts [16], maize flour [17], wheat [18], and soy bean flour [19]. However, the functional and nutritional properties of products made from a combination of RWD dried cowpea leaf powder and other foods are not well documented. To effectively, advocate for production, preparation and consumption of composite flour of RWD dried cowpea leaves, blended with maize and millet flours, there is need to generate data on acceptability and nutrient composition of the composites. 


\section{MATERIALS AND METHODS}

\section{Collection and preparation of raw materials}

Cowpea leaf batches with stalks were procured from farmers in Budondo sub-county, Jinja district in eastern Uganda. The leaves were placed in an icebox and immediately transported to the Nutrition laboratory of Makerere University, Department of Food Technology and Nutrition in Kampala, Uganda. While at the laboratory, the leaves on the plant were removed from their stalks by hand, and thereafter sorted to remove wrinkled, bruised and bleached leaves. The leaves were then rinsed with clean running tap water to remove dirt and other foreign matter. The millet (Eleusine coracana) flour and maize (Zea mays) flour were purchased from Wandegeya market in Kampala City. Cowpea leaf powder was obtained after successfully drying the leafy vegetables using refractance window drying (RWD) technology at $95^{\circ} \mathrm{C}$ for 1 hour for maximum nutrient retention. The RWD dryer (MCD Technologies, Inc. Tacoma, Washington, USA), was used to dry the fresh cowpea leaves. The dryer had a conveyer belt on which a thin layer of fresh cowpea leaves were placed. The conveyor rotated at a speed of $1.04 \mathrm{~m} / \mathrm{min}$, over the hot water at $95^{\circ} \mathrm{C}$ beneath, transported the drying leaves through a cooling section, before the dried cowpea leaves were dropped into a container, at the end. Dried leaves were packed in vacuum polyethylene bags for further analysis.

\section{Determination of optimum level of cowpea-millet and cowpea-maize flour incorporation}

Nutri Survey linear programming software was used to guide the rationing of flour ingredients to produce the composite flours [20]. The nutrients optimised were protein, carbohydrates and dietary fat. The rationing was done to ensure that the formulation provided $100 \%$ of the daily recommended proteins intake $(14 \mathrm{~g} /$ day $)$ in a single meal for infants aged between (6-12 months) and (20 g/day) children aged (1-8 years) [21,22]. The software recommendation ratios of 2:8 for cowpea-millet composite and 1:9 ratio for cowpea-maize composite, meeting the proteins requirements were adapted for this study.

\section{Preparation of composite porridges}

The cowpea-millet composite porridge was prepared by mixing $60 \mathrm{~g}$ ( $12 \mathrm{~g}$ of cowpea and $48 \mathrm{~g}$ of millet) of the composite flour, while the cowpea-maize porridge was produced by mixing $60 \mathrm{~g}$ ( $6 \mathrm{~g}$ of cowpea and $54 \mathrm{~g}$ of maize flour), with $150 \mathrm{ml}$ of cold water in the saucepan. The mixture was heated to boiling point. About $25 \mathrm{~g}$ of sugar was added to the boiling porridge and stirred to dissolve the sugar. Hot water was added to the boiling porridge until it topped up to $1000 \mathrm{ml}$. The mixture was left to boil for 2-3 mins while stirring and then removed from the cooking stove to cool.

\section{Sensory acceptability of the cowpea porridge blends}

Sensory properties of the two porridge blends were assessed by 106 untrained female panellists drawn from communities of Kayunga district. About $30 \mathrm{ml}$ of the samples were served warm following the recommended practices [10]. The ages of female panellists ranged from 13 to 60 years with majority falling in the range of reproductive age bracket. The untrained female panellists in this age bracket were preferred because 


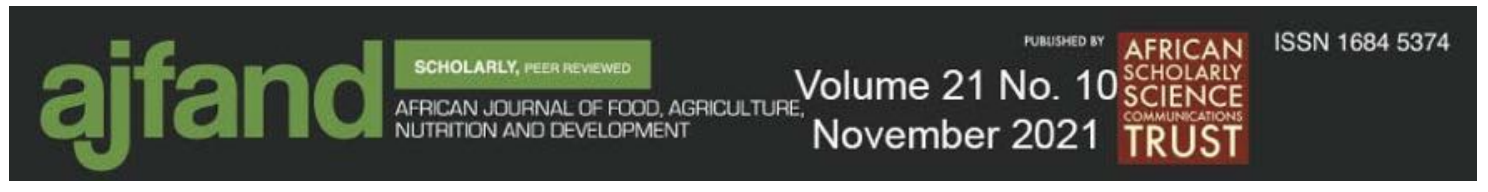

their view would reflect the actual perception of the product by children. Each panellist was provided with drinking water to rinse the mouth after each taste. The sensory attributes of porridges that were assessed were colour, aroma, texture, taste and general appearance of the porridge combinations. A five-point Likert-scale ranging from $1=$ dislike very much, $2=$ dislike it, $3=$ neither like or dislike it, $4=$ like it, $5=$ like it very much was used for the assessment [10].

\section{Proximate composition of the flours Protein determination}

Total crude protein content was determined using the Kjeldahl 984.13 method [23]. About $0.5 \mathrm{~g}$ each of the two porridges, were mixed with $10 \mathrm{ml}$ of concentrated sulphuric acid and digested with a Kjeldahl digester (Model Bauchi 430). About $40 \mathrm{ml}$ of water was added to the digest and distilled using a Kjeldahl distillation unit (Model unit B-316). Liberated ammonia was collected in $20 \mathrm{ml}$ boric acid with bromocresol green and methyl red indicators and titrated against $0.04 \mathrm{~N}$ sulphuric acid $\left(\mathrm{H}_{2} \mathrm{SO} 4\right)$. Crude protein was determined by multiplying nitrogen content by a factor of 6.25 .

\section{Determination of carbohydrate}

Carbohydrate content was determined by the phenol-sulphuric acid method [24]. One gram of the sample was mixed with $5 \mathrm{ml}$ of $2.5 \mathrm{~N}$ hydrochloric acid $(\mathrm{HCl})$ and boiled in a water bath for 3 hours to hydrolyse the sugars. After cooling, $100 \mathrm{ml}$ of solid sodium carbonate was added until the effervescence stopped. The mixture was filtered and made up to the mark using distilled water in a $100 \mathrm{ml}$ volumetric flask. Into a test tube, $5 \mathrm{ml}$ of sample was pipetted and $1 \mathrm{~m}$ of $5 \%$ phenol solution added. After shaking well, $5 \mathrm{ml}$ of concentrated sulfuric acid $(96 \%)$ was added after which the mixture was vortexed and then left to stand for 10 minutes. Absorbance of the sample was read at $490 \mathrm{~nm}$ using a spectrophotometer (Spectroquant Pharo ${ }^{\circledR}$ 300, EU) [24]. A standard curve was developed using glucose standards of varying concentration ( 0.01 to 0.1 $\mathrm{mg} / \mathrm{ml}$ ). The total amount of carbohydrate in the sample derived from glucose standard graph was expressed as $\mathrm{g} / 100 \mathrm{~g}$ of the powdered cowpea leaves.

\section{Lipid determination}

The total lipid content was determined using the ether extraction method 920.39 [23]. Crude lipid was extracted from the two cowpea composite porridges using $5 \mathrm{~g}$ for each sample of the extract in petroleum ether as a solvent and soxhlet extractor (Dijkstra Vereenigde BV, Lelystad, The Netherlands). After evaporation of the petroleum ether, the weight of the lipid obtained gave the crude lipid in the samples.

\section{Ash determination}

The inorganic matter (total ash) was determined using method 942.05 [23]. The organic matter of the two cowpea composite porridges was removed by heating them at $550^{\circ} \mathrm{C}$ overnight and the residue being the inorganic matter (ash).

$$
\frac{\text { Weight of crucible and ash }- \text { weight of crucible }}{\text { Weight of crucible and sample }- \text { weight of crucible }} \times 100
$$




\section{Dietary fiber determination}

The total dietary fibre content was determined using the method 978.10 [23]. Five grams of the samples, were used to determine the fibre content by acid digestion, filtration and base digestion. The resulting residues were eventually ignited at $550^{\circ} \mathrm{C}$ in a muffle furnace. Crude fibre content was expressed as a percentage lost on ashing, compared to the initial weight.

\section{Data analysis}

All experimental samples were prepared in triplicate ready for analysis. Data were analysed using XLSTAT (version 2012.10.7.01 Addinsoft, Paris France), to generate the analysis of variance (ANOVA) and to determine variation between means of cowpea-millet and cowpea-maize based composite porridges for their nutrient composition, and sensory properties of the porridges prepared from the two composites flours. The nutrient contribution of an average daily consumption of the two composite cowpea porridges in the present study, to nutrient intake recommendations of infants aged 6-12 months and children aged of 1-8 years, were computed and expressed as a percentage of the recommended dietary allowances (RDA) [21, 25]. During the computation of contributions towards the RDAs, the digestibility and bioavailability of proteins and other nutrients were taken into consideration [21, 22]. The macronutrients (proteins, carbohydrates and fat) contributions were calculated based on total daily food intake estimations of children reported by Otten et al and Fungo et al [21,22], where infants aged 6 to 12 months and children aged 1 to 8 years in Uganda consume about $200 \mathrm{~g}$ daily as reported by Kikafunda et al. [26]. Using these daily porridge intake estimates per individual, the potential contributions of the composite porridges on the daily nutrients requirements among children was calculated.

\section{RESULTS AND DISCUSSION}

\section{Proximate composition of the composite porridges}

The present study revealed that addition of cowpea flour to either millet or maize flours, remarkably improved the concentration of proteins, dietary fiber and fat in the composite porridges compared to the contents of these nutrients registered in porridges of only plain flour maize or millet (Table 1). The high nutrient content registered in the two composite porridge blends can be attributed to the optimal drying conditions of refractance window drying (RWD) technology. Leafy vegetables dried using RWD technology were exposed to temperatures of $95^{\circ} \mathrm{C}$ for a short time (approximately 10 minutes), with the final products retaining nutrients and maintaining good sensory qualities, such as colour and aroma [11, 27, 28]. For example, the protein contents of the two cowpea based composite flours significantly $(p<0.05)$ increased from 10.96 $\mathrm{g} / 100 \mathrm{~g}$ in plain millet porridge to $13.4 \mathrm{~g} / 100 \mathrm{~g}$ in cowpea-millet composite porridge, and from $5.91 \mathrm{~g} / 100 \mathrm{~g}$ in plain maize porridge to $7.6 \mathrm{~g} / 100 \mathrm{~g}$ in cowpea-millet porridge. Then again, the dietary fiber contents significantly $(\mathrm{p}<0.05)$ increased from 11.01 $\mathrm{g} / 100 \mathrm{~g}$ in plain millet porridge to $12.5 \mathrm{~g} / 100 \mathrm{~g}$ in the composite cowpea-millet porridge. It was further observed that addition of millet and maize flours to the cowpea powder slightly improved the lipids and ash contents of both cowpea-millet and cowpea-maize composite flours. 
It has been reported elsewhere, that the blending of two or more plant-based food materials especially when flours of legumes are blended with cereal flours, remarkably increases the nutrient density of the resulting food product [29]. Therefore, the addition of RWD technology dried leaves of cowpea a legume, to the flours of cereals of millet and maize respectively, boosts the nutrient contents of the cowpea-based composite flours. Legumes including cowpeas generally contain higher nutrient content than cereals, especially the amino acid content [30]. Mariam [31] reported an increment in the protein content to $65 \%$ of a composite food formulated, by blending flours of millet, soybeans, rice and peanut oil. The high nutrient contents in the composite flours porridge blends in the present study, may provide a cheap and alternative source of proteins and other nutrients to the rural populations in Uganda. In the present study, the carbohydrate contents of $64.2 \mathrm{~g} / 100 \mathrm{~g}$ registered in cowpea-millet composite porridge and $88.8 \mathrm{~g} / 100 \mathrm{~g}$ registered in cowpea-maize composite are superior to the maize-wheat composites with $59.99 \%$ reported by Ajifolokun et al. [32]. The dietary fiber content in the two composite flour porridge blends compares well with the contents of $5.71 \%$ reported in cowpea-millet porridges in Nigeria [32] and in maize bean flour blends consumed by the Nandi communities in Kenya [33]. Adequate intake of dietary fiber is reported to have medical benefits of lowering the risk of colon cancer, constipation and many other digestive disorders and diseases [34]. The lipid contents of the two composite flours in the present study are about two fold, the content $(2.67 \%)$ registered in Ugandan composite blends of maize and bean flours [35]. Based on the high fat content of the mixed flour blends, they are good sources of energy in diets.

\section{Sensory acceptability of the cowpea porridge blends}

The consumer acceptability of the porridges in the present study was much dependent on the sensory attributes such as colour, aroma, taste and mouth feel texture (Table 2). Generally, between the two composite cowpea porridges, the cowpea-millet porridge blend was significantly $(\mathrm{P} \leq 0.05)$ more appealing in terms of colour $(3.61 \pm 0.8)$, aroma $(2.96 \pm 0.2)$, taste $(3.24 \pm 0.6)$ and texture $(3.62 \pm 0.6)$ to the panellists than the cowpeamaize porridge blend. The panellists preferred the cowpea-millet because it had almost similar sensory characteristics to the plain millet porridge they are used to. The significant variations in the mean liking scores among cowpea-millet porridges and cowpea-maize porridges may be attributed to the millet flour having significantly influenced the sensory acuity and acceptability of the samples. The findings in the present study are in agreement with findings reported elsewhere in sorghum-millet porridges formulated in Nigeria [36], cassava-millet porridges formulated in Uganda [37] and complimentary porridge of millet, soybeans and grayfish powder developed in Nigeria [38].

On the contrary, scores for overall acceptability revealed that the plain millet $(4.54 \pm 0.3)$ and maize $(4.29 \pm 0.1)$ porridges were more significantly $(\mathrm{p} \leq 0.05)$ acceptable than composite cowpea-based millet $(3.61 \pm 0.8)$ and composite cowpea maize $(3.39 \pm 0.1)$ porridge. Similar trends were observed for colour, aroma, taste and texture. The higher acceptability of the plain millet and maize porridges than the cowpea-millet and cowpea-maize porridges can be attributed to the fact that the consumers were more familiar to the plain porridge blends [39] than the composite porridge blends. Bhuiyan [40] previously attributed the preference of plain millet porridge to its peculiar aroma, 
colour and texture, that is appealing to children and women. Also, the low preference of composite porridges, in the present study, can be attributed to the green pigmentation of the cowpea powder, which was introduced in the blends of cowpea-millet porridge and cowpea-maize porridge, lowering the consumers' appeal to the mixed porridges. The green coloration in foods is highly correlated with the salt related foods such as soups and sauces but not the sugar related foods such as porridges [41].

\section{Contribution of the composite porridges to the daily requirements of proteins, carbohydrates and fats of infants (6-12 months) and children (1-8 years)}

The amount of foods (such as porridges) eaten habitually by children in rural settings of Africa and Uganda in particular, is estimated at around $200 \mathrm{~g}$ daily for infants aged 6 to 12 months and children aged 1 to 8 years [42]. Porridges are often eaten daily by children as a main meal, sometimes between main meals or while guardians perform household income activities such as farming [43]. Consequently, using these approximations for the amounts of porridge that may be consumed, the likely contributions of the two composite porridges of cowpea-millet and cowpea-maize were estimated, to meet the RDAs of proteins, carbohydrates and fats [21, 22]. The calculated potential contribution of the two porridges in the present study in reference to intakes of the proteins, carbohydrates and fats revealed that these porridges can provide substantial amounts of nutrients to both infants (6 to 12 months) and children aged 1-8 years (Table 3 ). For both infants and children the two composites of porridges can contribute $100 \%$ RDAs daily protein and carbohydrate requirements. The high contribution of the composite flours of cowpea-millet to RDAs for protein and carbohydrates is due to the high carbohydrate and protein concentration in both the cowpea and millet flour. The protein and carbohydrates contribution from the two composite porridges, are above the RDAs for proteins and carbohydrates. The findings revealed that the contribution of the two porridges towards proteins and carbohydrates RDAs reduced, with increase in the age of infants and children. This may be due to an increase in the body needs during growth. For example, energy is needed for maintaining body size, body composition and a desirable physical activity and to allow optimal growth and development among children, deposition of tissues, while protein is for growth and development in children [44]. Results further revealed that if an infant aged 6-12 months was fed 200g of cowpea-millet porridge or cowpea-maize porridge respectively, $38 \%$ or $30 \%$ of his or her daily fat requirements would be met. Fats are essential in the body for; calorie supply, brain development, absorption and transportation of vitamins (33-34). In order to meet the protein, fat, and energy RDAs of the older children, intake of more than $200 \mathrm{ml}$ of the millet based composite porridge is recommended.

\section{CONCLUSION}

The refractance window dried cowpea leaves flour blended with millet or maize flours significantly improved the nutrient content of the composite porridges. Addition of cowpea flours in composite porridge formulations of either millet or maize, negatively affected the sensory characteristics of composite porridges. Composite cowpea-millet porridges were the most preferred with regards to their sensory characteristics, when compared with cowpea-maize porridges. Given the high protein and carbohydrate 


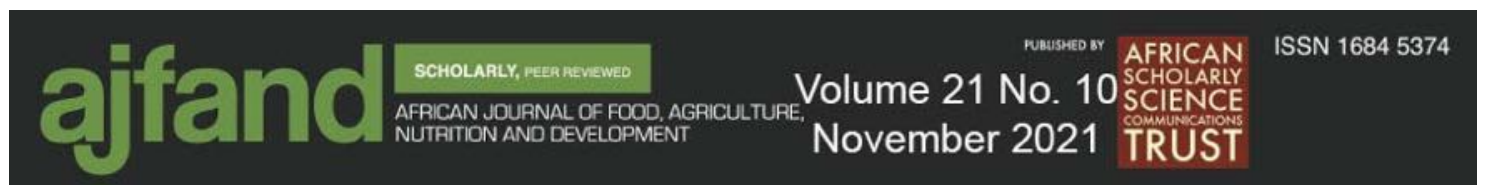

content of the two porridge composites, it can be concluded that the two composite porridges can make considerable contributions towards meeting protein and carbohydrate requirements for infants (6-12 months) and children (1-8 years).

\section{ACKNOWLEDGEMENTS}

This work was supported by the Fruits and Vegetables for all Seasons (FruVaSe) project funded by the Georg - August- University of Göttingen Division Quality of Plant Crops, Department of Crop Sciences in partnership with School of Food Technology, Nutrition and Bioengineering, Makerere University.

\section{ETHICAL REVIEW}

The Ethics Committee of Makerere University concluded that cowpea and composite samples were not toxic to humans testing, in the quantities and concentrations that were served. A copy of the document approving the study was shared to reassure the panellists recruited.

\section{CONFLICT OF INTEREST}

The authors declare no conflict of interest. 


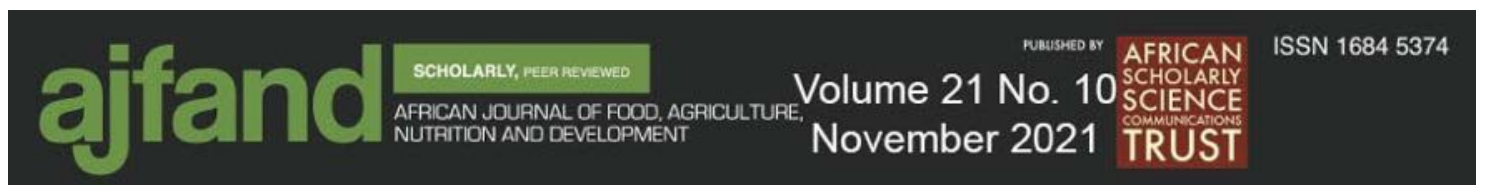

Table 1: Proximate composition of the different flour blends (g/100g)* on dry weight basis

\begin{tabular}{lccccc}
\hline Flour blends & Protein & Carbohydrates & Dietary fiber & Lipid & Ash \\
\hline $\begin{array}{l}\text { Plain millet } \\
\text { porridge }\end{array}$ & $10.96^{\mathrm{a}} \pm 2.01$ & $71.02^{\mathrm{d}} \pm 0.05$ & $11.01^{\mathrm{a}} \pm 1.93$ & $4.71^{\mathrm{b}} \pm 0.35$ & $1.57^{\mathrm{c}} \pm 0.31$ \\
$\begin{array}{l}\text { Millet porridge } \\
\text { with CLP }\end{array}$ & $13.4^{\mathrm{b}^{\mathrm{a}} \pm 0.09}$ & $64.2^{\mathrm{b}} \pm 0.82$ & $12.5^{\mathrm{a}} \pm 0.58$ & $5.3^{\mathrm{a}} \pm 0.73$ & $3.4^{\mathrm{a}} \pm 09$ \\
$\begin{array}{l}\text { Plain maize } \\
\text { porridge }\end{array}$ & $5.91^{\mathrm{c}} \pm 0.03$ & $88.79^{\mathrm{c}} \pm 0.73$ & $1.47^{\mathrm{b}} \pm 0.02$ & $2.84^{\mathrm{d}} \pm 0.80$ & $1.35^{\mathrm{c}} \pm 0.07$ \\
$\begin{array}{l}\text { Maize porridge } \\
\text { with CLP }\end{array}$ & $7.6^{\mathrm{C}} \pm 0.52$ & $84.1^{\mathrm{a}} \pm 0.13$ & $3.1^{\mathrm{c}} \pm 0.63$ & $3.3^{\mathrm{c}} \pm 0.43$ & $2.3^{\mathrm{b}} \pm 0.21$ \\
& & & & &
\end{tabular}

CLP-Cowpea leaf powder

*Values are means and standard deviation of three determinations.

Means in the same column with the same superscript letter are not significantly different determined by ANOVA test $(\mathrm{P}>0.05)$

Table 2: Sensory acceptability scores on a 5-point Likert scale for porridge made from the cowpea- based composite flours

\begin{tabular}{lccccc}
\hline Factor & $\begin{array}{c}\text { General } \\
\text { acceptability }\end{array}$ & Color & Aroma & Taste & Texture \\
\hline Plain millet porridge & $4.54^{\mathrm{a}} \pm 0.3$ & $4.26^{\mathrm{a}} \pm 0.5$ & $3.97^{\mathrm{a}} \pm 0.6$ & $4.27^{\mathrm{a}} \pm 0.4$ & $4.34^{\mathrm{a}} \pm 0.5$ \\
Millet porridge with CLP & $3.61^{\mathrm{b}} \pm 0.8$ & $3.32^{\mathrm{b}} \pm 0.8$ & $2.96^{\mathrm{b}} \pm 0.2$ & $3.24^{\mathrm{b}} \pm 0.6$ & $3.62^{\mathrm{b}} \pm 0.6$ \\
Plain maize porridge & $4.29^{\mathrm{a}} \pm 0.5$ & $3.78^{\mathrm{b}} \pm 0.3$ & $3.74^{\mathrm{a}} \pm 0.4$ & $4.16^{\mathrm{a}} \pm 0.7$ & $3.98^{\mathrm{b}} \pm 0.2$ \\
Maize porridge with CLP & $3.39^{\mathrm{b}} \pm 0.1$ & $2.66^{\mathrm{c}} \pm 0.7$ & $2.87^{\mathrm{b}} \pm 0.1$ & $3.18^{\mathrm{b}} \pm 0.4$ & $3.28^{\mathrm{c}} \pm 0.5$ \\
\hline
\end{tabular}

CLP-Cowpea leaf powder

*Values are means and standard deviation of three determinations.

Means in the same column with the same superscript letter are not significantly different determined by

ANOVA test $(\mathrm{P}>0.05)$ 


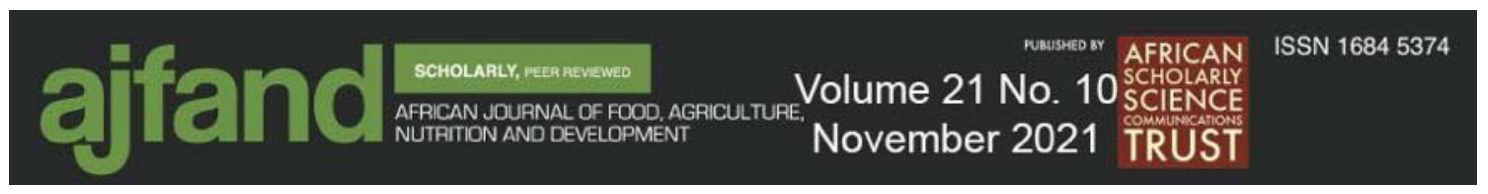

Table 3: Percentage contribution of composite cowpea porridges $(200 \mathrm{~g}$ among children) to the daily requirements of proteins, carbohydrates and fats of infants (6-12 months) and children (1-8 years)

\begin{tabular}{lccc}
\hline & \multicolumn{2}{c}{ Percentage contribution to RDAs infants and children } \\
\hline Variable & Age group & $\begin{array}{c}\text { Cowpea-millet } \\
\text { porridge }\end{array}$ & $\begin{array}{c}\text { Cowpea - maize } \\
\text { porridge }\end{array}$ \\
\hline Proteins $^{b}$ & $0-6$ moths & 960 & 660 \\
& $7-12$ months & 794 & 546 \\
& $1-3$ years & 672 & 462 \\
Carbohydrates & 4-8 years & 460 & 316 \\
& $0-6$ months & 316 & 444 \\
& 7-12 months & 199.6 & 280 \\
Fat & $1-3$ years & 146 & 205 \\
& 4-8 years & 144 & 205 \\
& $0-6$ months & 36 & 30 \\
& $7-12$ months & 38 & 30 \\
& $1-3$ years & ND & ND \\
& $4-8$ years & ND & ND
\end{tabular}

Source: Food and Nutrition Board, (2003), Institute of Medicine, National Academies

*Adequate Intakes (AIs)

${ }^{b}$ Based on g protein per kg of body weight for the reference body weight, e.g., for adults $0.8 \mathrm{~g} / \mathrm{kg}$ body weight for the reference body weight

${ }^{\mathrm{c}}$ Not determined 


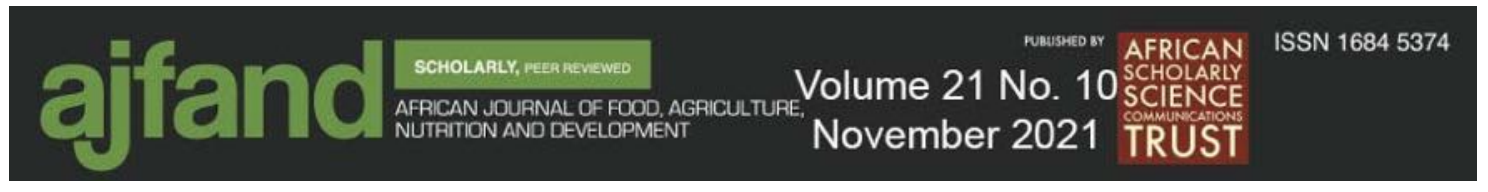

\section{REFERENCES}

1. Ronner $\mathbf{E}$ and KE Giller Background information on agronomy, farming systems and ongoing projects on grain legumes in Uganda, www.N2Africa.org pp. 2012;17-18.

2. Ddungu S, Ekere W, Bisikwa J, Kawooya R, Okello Kalule D and M Biruma Marketing and Market Integration of Cowpea (Vigna unguiculata L. Walp) in Uganda. J. Dev. Agric. Econ, 2015; vol. 7, no. 1: 1-11.

3. De Groote H, Kimenju SC and UB Morawetz Estimating consumer willingness to pay for food quality with experimental auctions: The case of yellow versus fortified maize meal in Kenya. Agric. Econ. 2010;42: 1-16.

4. Bouis HE and A Saltzman Improving nutrition through biofortification: A review of evidence from HarvestPlus,2003 through 2016. Glob. Food Secur 2017; 12: 49-58.

5. Oulai PD, Zoue LT and SL Niamke Evaluation of nutritive and antioxidant properties of blanched leafy vegetables consumed in Northern Côte d'Ivoire. Pol J. Food Nutr. Sci.2015; 65: 31-38. https://doi.org/10.1515/pjfns-2015-0003

6. Nekesa C Nutrient and antinutrient content in leaves of selected Coastal Kenya cassava varieties as affected by maturity stage, leafage and preparation method. Msc Thesis. 2016 Nairobi, Kenya: University of Nairobi.

7. Kirakou SP, Margaret HJ, Ambuko J and WO Owino Efficacy of blanching techniques and solar drying in maintaining the quality attributes of cowpea leaves. African Journal of Horticultural Science 2017; 11: 18-34.

8. Madode YE Keeping local foods on the menu: a study on the small-scale processing of cowpea. Wageningen University 2012.

9. Moyo SM, Serem JC, Bester MJ, Mavumengwana $\mathbf{V}$ and E Kayitesi African Green Leafy Vegetables Health Benefits Beyond Nutrition, Food Reviews International, 2020 https://doi.org/10.1080/87559129.2020.1717519

10. Ndagire CT, Muyonga JH, Manju R and D Nakimbugwe Optimized formulation and processing protocol for a supplementary bean-based composite flour. Food Sci and Nutri, 2015; 3(6): 527-538.

11. Nindo CI and J Tang Refractance window dehydration technology: A novel contact drying method. Drying Techn, J 2007; 25(1): 37-48.

12. Shende $\mathbf{D}$ and AK Datta Optimization study for refractance window drying process of Langra variety mango. J. Food Scie and Tech 2019 https://doi.org/10.1007/s13197-019-04101-0 


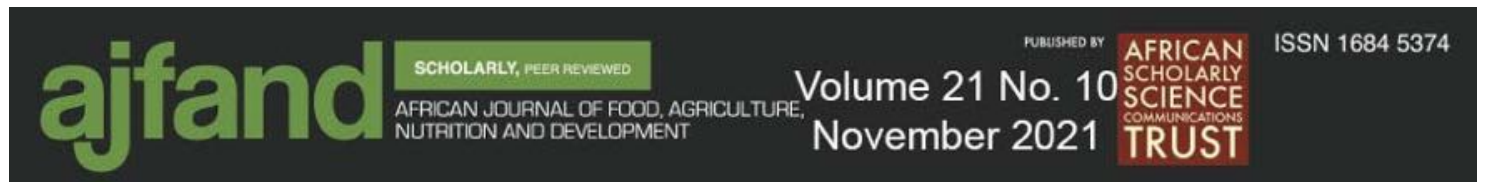

13. Malleshi NG, Daodu MA and A Chandrasekhar Development of weaning food formulation based on malting and roller drying of sorghum and cowpea. Int. J. Food Sci. Technol. 1989; 24:511-519.

14. Iwe MO, Onyeukwu U and AN Agiriga Proximate, functional and pasting properties of FARO 44 rice, African yam bean and brown cowpea seeds composite flour. Cogent Food Agric. 2016; 2: 1142409.

15. McWatters KH, Hung CYT, Hung YC, Chinnan MS and RD Phillips Akara making characteristics of five US varieties of cowpeas (Vigna unguiculata). $J$. Food Qual. 2001; 24: 53-65.

16. Alain MMM, Israel ML and MS Rene Improving the nutritional quality of cowpea and bambara bean flours for use in infant feeding. Pak. J. Nutr., 2007 ;6(6): 660-664.

17. Jirapa P, Normah H, Zamaliah M, Asmah R and K Mohammad Nutritional quality of germinated cowpea flour (Vigna unguiculata) and its application in home prepared powder weaning foods. Plant Foods Human Nutr., 2001 ;56: 203216.

18. Mcwatter KH, Phillips RD, Walker SL, Mccullough SE, Mensa-Wilmot Y, Saalia FK, Hung YC and SP Patterson Baking performance and consumer acceptability of raw and extruded cowpea flour breads. J. Food Quality, 2004; 27(5): 337-351.

19. Oyeleke OA, Morton ID and AE Bender The use of cowpeas (Vigna unguiculata) in improving a popular Nigerian weaning food. Br. J. Nutr., 1985 ;54: 343-347.

20. NutriSurvey for window [program], 2004. http://www.nutrisurvey.de/lp/lp.htm

21. Otten JJ, Hellwig JP and LD Meyers Dietary Reference Intakes: The Essential Guide to Nutrient Requirements; The National Academies Press: Washington, DC, USA, 2006. https://doi.org/10.1093/ajen/85.3.924

22. Fungo R, Muyonga JH, Ngondi JL, Mikolo-Yobo C, Iponga DM, Ngoye A, Nchuaji Tang $\mathbf{E}$ and $\mathbf{J}$ Chupezi Tieguhong Nutrient and Bioactive Composition of Five Gabonese Forest Fruits and Their Potential Contribution to Dietary Reference Intakes of Children Aged 1-3 Years and Women Aged 19-60 Years. Forests, (2019) 10(2), 86. https://doi.org/10.3390/f10020086

23. AOAC. Official Methods of Analysis, 18th edn. Association of Official Analytical Chemists, Gaithersburg, MD 2005.

24. Fournier E Colorimetric quantification of carbohydrates. In Current Protocols in Food Analytical Chemistry. Wrolstad, R.E. (ed.). Hoboken, NJ, USA: John Wiley and Sons, E1.1.1-E1.1.8, 2001. 


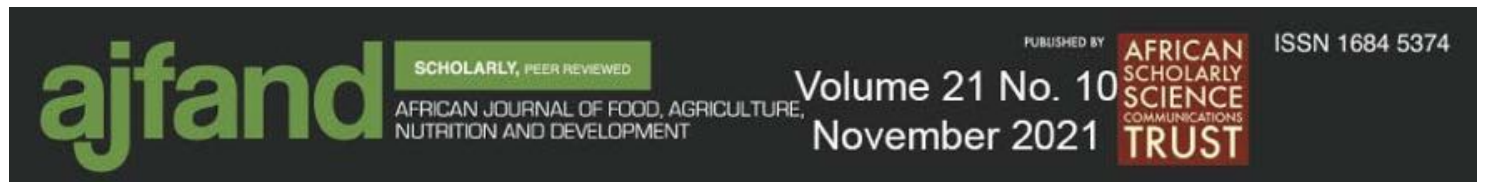

25. Institute of Medicine. Dietary Reference Intakes for Energy, Carbohydrate, Fiber, Fat, Fatty Acids, Cholesterol, Dietary contribution of forest foods Protein, and Amino Acids. Washington, DC: National Academies Press 2005.

26. Kikafunda JK, Walker AF, Collett D and JK Tumwine Risk factors for early childhood malnutrition in Uganda. Pediatrics, 1998 102(4).

27. Karadbhajne SV, Thakare VM, Kardile NB and SM Thakre Refractance Window Drying: An Innovative Drying Technique for Heat Sensitive Product. Int J Recent Technol Eng., 2019 ;8 (4):1765-1771.

28. Abonyi BI, Juming T and CG Edwards Evaluation of Energy Efficiency and Quality Retention for the Refractance Window TM Drying System. Systems Engineering, 1999 1-38.

29. Leonel M, Souza LB and MM Mischan Thermal and pasting properties of cassava starch-dehydrated orange pulp blends. Sci. Agric, 2011; 68: 342-346.

30. Nnam NM and GT Baiyeri Evaluation of the nutrient and sensory properties of multimixes and porridges made from maize, soybean, and plantain for use as complementary food. Ecol Food Nutr, 2008 ;47(1): 64-76.

31. Mariam S Nutritive Value of Three Potential Complementary Foods Based on Cereals and Legumes. African J. Food, Agric. Nutr, 2005 ;5(2): 3-15.

32. Ajifolokun O, Basson A, Osunsanmi F and GE Zharare Nutritional Composition and Organoleptic Properties of Composite Maize. J. Food Process. Technol. 2019 10;798(6): 1-4.

33. Gitau PW Processing Analysis and nutritional Quality of Porridge composite Flours Developed from Legume-based Ingredients grown in Nandi County. University of Nairobi Department of Food Science, Nutrition and Technology. 2018139.

34. Okonya JS and BL Maass Potential of cowpea variety mixtures to increase yield stability in subsistence agriculture: Int. J. Agron.2014.

35. Kikafunda JK, Abenakyo L and FB Lukwago Nutritional and sensory properties of high energy/nutrient dense composite flour porridges from germinated maize and roasted beans for child-weaning in developing countries: A case for Uganda. Ecol Food Nutr 2006; 45(4): 279-294.

36. Gabriel-Ajobiewe RAO, Cyril-Olutayo MC, Olumekun VO and FJ Akinbileje Effect of Bambusa tuldoides cv. ventricosa leaf extracted with fermented steep liquors of maize and sorghum on some pathogenic organisms. Malays. J. Microbiol. 2014; 10 (4): 280-289. 


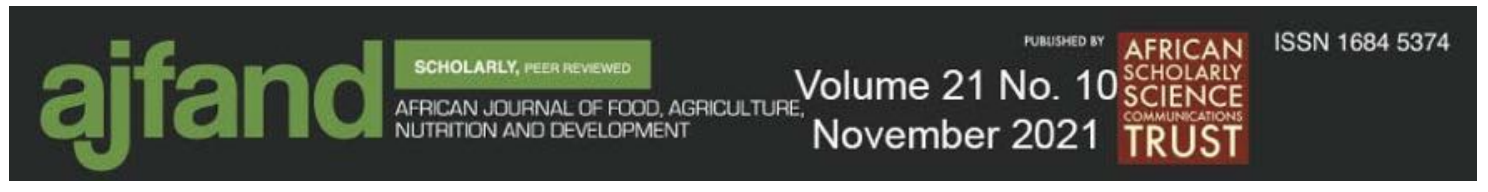

37. Tibagonzeka J, Wambete $\mathbf{J}$, Muyinda A $\mathbf{M}$ and DM Nakimbugwe Acceptability and Nutritional Contribution of Grain Amaranth Recipes in Uganda. AFJAND, 2014 ;14(3): 8979-8997.

38. Lombor TT, Umoh EJ and E Olakumi Proximate Composition and Organoleptic Properties of Complementary Food Formulated from Millet (Pennisetum psychostachynum), Soyabeans (Glycine max) and Crayfish (Euastaeus spp). Pak. J. Nutr. 2009 ;8 (10): 1676-1679.

39. Kayitesi E, Duodu KG, Minnaar A and HL de Kock Sensory quality of marama/sorghum composite porridges. J Sci Food Agr2010 ;90(12): 2124-2132.

40. Bhuiyan RF Consumer's Sensory Perception of Food Attributes: A Survey on Flavor. J. Food and Nutr Sci. Nutr., 2015; 3(1): 157.

41. König LM and B Renner Exploring meal colour variety and its relation to food consumption. Food Qual Prefer, 2018;64 (July 2017): 66-71.

42. Susan B Sustainable development and consumption: The ambiguities - The Oslo ministerial roundtable conference on sustainable production and consumption, Oslo, 6-10 February 1995. Environ. Politics 1996; 5: 93-99.

43. Fungo R, Muyonga J, Kabahenda M, Kaaya A, Okia C, Donn P, Tchtat M, Tchingsabe $\mathbf{O}$, Tieguhong JC, Loo J and L Snook Contribution of forest foods to dietary intake and their association with household food insecurity: a crosssectional study in women from rural Cameroon. Public Health Nutrition 2016 Dec;19 (17):3185-3196. https://doi.org/10.1017/S1368980016001324

44. Wurtman RJ, Wurtman JJ, Regan MM, McDermott JM, Tsay RH and JJ Breu Effects of normal meals rich in carbohydrates or proteins on plasma tryptophan and tyrosine ratios. Am J Clin Nutr 2003; 77:128-32. 